\title{
Assessing the Effect of Training of Traditional Bone Setters in Enugu State South East Nigeria
}

\author{
Dr. Ifeanyi Eyisi \\ Department of Community Medicine, College of Medicine \\ Chukwuemeka Odimegwu Ojukwu University, Anambra, Nigeria
}

\begin{abstract}
In Nigeria, the traditional bone setters, perhaps more than any other group of traditional health provider enjoy high patronage and confidence by the society. ${ }^{5,6}$ Indeed, the patrons of this service cut across every strata of the society including the educated and the rich. ${ }^{5-7}$ The origin of the practice is shrouded in mystery but passed on by practitioners from one generation to another ${ }^{8-10}$.

Methods: Bivariate analysis was used with the aid of SPSS Version 16 and Epi-info version 6; respondents were described by their socio-demographic characteristics, a comparison of intervention and control group were checked with the chi-square analysis at base line to determine the differences in their knowledge and practice of Traditional bone setters on traditional bone setting. It was also carried out at post-intervention period (6 months after intervention) to determine the effect of training of traditional bone setters on the uptake of X-ray services, modern orthopedic practices, POP, anti-tetanus injections, antibiotics and insecticide treated nets.

Results: The general knowledge of bone setting by the respondents improved after training, except in the need to provide the in-patients with ITNs which recorded no change. After the training, all the traditional bone setters knew the importance of having nurses and other paramedical staff in their clinics $(p=0.000)$. The signs and symptoms of wound and tetanus infection did not change after training. However, the need for sterilization of instruments and hygienic dressing improved significantly after training $(p=0.000)$. Equally, the knowledge of the need for POP improved significantly $(\mathrm{p}=0.005)$. Interestingly, the acknowledgement that continual adjustment of splitting could lead to mal-union or non-union improved statistically after training $(p=0.000)$. The practice of bone setting by TBSs in the study group after training statistically improved. The acceptance of training of other people in the clinics and use of antibiotics/anti-tetanus toxoid were statistically significant after training of the TBS in the study group. Interestingly, the referral of patients with serious fracture to orthopedic surgeons for better management improved significantly after training $(\mathrm{p}=0.039)$.

Conclusion: From the study, there were remarkable improvements in the management of bone fracture by TBSs after training. The knowledge, attitudes and practices of TBSs improved significantly after training on basic orthopedic practices. There was also an improvement on prompt referral of serious fractures to orthopedic surgeons for better management.
\end{abstract}

Keywords: ITN; Traditional Bone Setting; TBS; ITN; Orthopaedic surgeons

DOI: $10.7176 / \mathrm{JHMN} / 58-08$

\section{Introduction}

As obtainable in Nigeria and other parts of the developing world, traditional medicine practitioners have been in existence before the advent of orthodox medicine, traditional medicine was the only available form of healthcare. ${ }^{1-4}$ Presently both orthodox and traditional medicine coexist side by side and patronized by partients..$^{1-4}$

In Nigeria, the traditional bone setters, perhaps more than any other group of traditional health provider enjoy high patronage and confidence by the society. ${ }^{5,6}$ Indeed, the patrons of this service cut across every strata of the society including the educated and the rich. ${ }^{5-7}$ The origin of the practice is shrouded in mystery but passed on by practitioners from one generation to another ${ }^{8-10}$. The practitioners keep it as a family secret. ${ }^{4,8,9,11}$ One of the most important flaws of the practice of traditional bone setters(TBS) presently in Nigeria is the process of training and acquiring skills in bone setting, which is not formal, undocumented and uncontrolled with attendant continuous decline in imparted knowledge and hoarding of information. ${ }^{2,3,4,12,13,14}$

Furthermore, the practice is passed on by oral tradition and there is no regulation, review and even peercriticism. Quality is therefore not guaranteed and complications are high. ${ }^{12,14,15,16,17}$ This is unlike orthodox training, which is regulated, open and subject to regular review on the basis of new evidences. ${ }^{2,3,4,16}$

In China and Europe the traditional bone setting had existed with orthodox cares together for decades. ${ }^{16-18}$ Indeed by 1949 there were about 500,000 Chinese - styled doctors trained in care of disease including pain control, fracture and sprains management. ${ }^{16-18}$ The practice is regulated and practitioners undergo structured training. ${ }^{17,18,19}$

In Turkey, TBS is regulated, there is continual structured training and the practitioners refer complicated cases to formal hospital promptly. ${ }^{17-19}$ In Nigeria, the reasons for patronage of traditional bone setters are cheaper fees, easy accessibility, quick services, cultural belief, utilization of incantations and concoctions and pressure from friends and families. ${ }^{5-7}$ The major reason is the perceived cheaper fees. ${ }^{5}$ However, this has been better 
characterized to be that multiple little payments are allowed by bone setters and even payments in kind with clothes live animals and even the offer women for marriage. ${ }^{5,6}$

In Nigeria, the age of patronizers of traditional bone setters vary from new born with musculo-skeletal deformity to the very elderly with fractures. ${ }^{5-7}$ The bulk of patronizers are male within the age of 15 years and 60 years due to upsurge in number of people operating commercial motorcyclists. ${ }^{5-7}$

In Nigeria, about $85 \%$ of patients with fractures present first to traditional bone setters. Indeed, in most of the communities' orthodox centers are several kilometers away from people. ${ }^{5-7}$ It is important to state that the patronage of traditional treatment in Nigeria is independent of socio-economic status and religious belief. ${ }^{5-7}$

\section{Statement of Problem}

Financial cost of the corrective treatment due to mismanagement by TBS ranged between 50,000 to 300,000 Nigeria Naira ${ }^{15}$ whereas the estimated cost of treating similar injuries when they are uncomplicated was about N7,500 to N70,000 Nigeria Naira. ${ }^{15}$ The number of complications seen in secondary/tertiary orthopedic centers are quite insignificant compared to the number that are languishing in the villages because of poverty and ignorance. ${ }^{2,3,15,18,19}$ There is also erroneous belief in traditional Africans that the only available option for treatment of fracture in hospital is amputation. ${ }^{15} \mathrm{Few}$ orthopaedic and trauma surgeons working in Africa are overburdened by these unnecessary complications as they spend their expertise correcting complication rather than practicing modern orthopaedic and research. ${ }^{15,17,18}$ The cost of correcting complications was very high so those who cannot afford were left to die or remain incapacitated for life. ${ }^{15,17,18}$ These complications pose economic, physical and social burden to the affected individuals, families and the society. ${ }^{15}$

The complication resulting from mismanagement by traditional bone setters (TBS) is usually a function of the method applied in treatment. Where splints have been applied, compartment syndrome, extremely gangrene and Volkmann ischaemia are known regular complications ${ }^{4,7}$ and where massaging with pulling are the preferred treatment option, they usually lead to heterotrophic ossification and non-union, while scarifications and open fractures have been known to lead to chronic osteomyelitis, sepsis and tetanus. Joint ankylosis, contracture wrist, herbal burns and nerve palsy. ${ }^{4}$

\section{Justification for the Study}

Most of the information on the subject of assessing the effect of training of traditional bone setters with success have been documented in Southwest, South-south and South east, Nigeria. ${ }^{4,5,6,7,8,9,10,23}$

Despite the previous work done, there is still high prevalence of bone complications due to TBS mismanagement mostly in rural areas of Enugu State, Nigeria. The high prevalence of bone complications may be due to societal confidence which the TBS enjoy with high patronage by people. ${ }^{5,6}$ In addition, most developing countries particularly the rural areas lack appropriate health care infrastructures and resources. Also no efforts by government to regulate TBS practices and establishment of a sound referral system and adoption of a standard training programme for TBS. ${ }^{4}$

\section{The Relevance of the Study to the Practice of Public Health}

A number of recent studies conducted in sub-Saharan Africa have provided evidence to prove that training of TBS can improve the deficiencies of traditional bone setters with resultant bone complications. ${ }^{4,10,15,16,19,20,21,22,23}$ In Nigeria, research had shown the training of TBS had reduced the prevalence of bone complications by TBS. ${ }^{4,10,15,16}$ Despite the growing evidence on the benefit of training of traditional bone setters, the available records on the burden of bone complications is not encouraging. ${ }^{4}$ This calls for more work to reduce the problems of bone complications by TBS.

This study was going to evaluate the training of traditional bone setters and this will be added to the pool of evidence needed by the policy makers for a better implementation of practices of traditional bone setters in Enugu State, Nigeria.

\section{Research Question}

1. Will training of TBS improve the management of bone fracture?

2. Will training of TBS improve prompt referral of cases?

\section{Hypotheses}

1. There is no significant difference in management of bone fractures by TBS after training.

2. There is no significant difference in referral of bone fracture cases by TBS. 


\section{General Objective}

\section{This research aims to assess the effect of training of TBS in Enugu State, South east Nigeria Specific Objectives}

1. To assess the knowledge of traditional bone setters (TBSs) on bone fracture management.

2. To assess the attitude of TBSs on bone fracture management.

3. To assess the practice of TBSs on bone fracture management.

4. To train TBSs on basic orthopedic practices and referral.

5. To assess the effect of training of TBSs and the outcome of their management of clients.

\section{Traditional Bone Setting}

The traditional healers are generally divided into traditional herbal healers, traditional birth attendants and traditional bone setters. ${ }^{1-4}$ Traditional bone setting is an ancient practice in Nigeria and other developing countries with little or no medical guidance. ${ }^{4}$ The TBS do not have organized training, need no license to practice and do not have a fixed fee in return for their services. ${ }^{4}$ Traditional bone setting is a family practice and training is by apprenticeship. ${ }^{3,4}$ The traditional bone setters develop their skills and experience by practice. ${ }^{4}$ They diagnose fractures by physical assessment and experience, but sometimes may ask for X-rays. ${ }^{4,8,9,10,11,12}$

There are some esoteric aspects to the TBS practice, including incantations, amulets and charms. ${ }^{15-19}$ This comes into play during the treatment of open fractures. Incantations are invoked to remove bone fragments from the fracture site. ${ }^{17-19}$ The bone is "commanded" to heal once the fragments are out. Amulets and charms are worn by the patient to ward off evil spirit, witches and wizards which are believed to hinder bone healing. ${ }^{17-19}$

In modern orthopedic practice in Nigeria, manipulation of a fracture is performed once adequate analgesic and anesthesia have been provided. ${ }^{4}$ Once the fracture is reduced, a plaster of Paris cast is applied to keep the reduction stable to aid in healing. The cast remains in place until fracture union; routine removal of cast, and recasting is not common in our contemporary orthopedic practice. ${ }^{4}$ Both effective analgesic and $\mathrm{x}$-ray are used in modern orthopaedic surgeries. ${ }^{4,19}$

The common method of immobilization used by traditional bone setters is a native splint which consists of bamboo or palm leaf axis sticks, that are knitted together to form a raff-like splint which is usually wrapped around the fracture site tightly and sometimes enforced by cloth bandage, , 20,21,22 $^{2}$

However, the practice is characterized by some draw backs such as the use of tight splint at fracture site without basic knowledge of anatomy, physiology or nursing care resulting in limb and life threaten complication such as non-union and gangrene, where massaging and pulling are used by TBS hetrotrophyic ossification and non-union. ${ }^{4,19,20,21,22}$ Poor observation of hygiene and scarification will lead to chronic osteomyelitis, sepsis, tetanus, hepatitis B and HIV infection. ${ }^{23-27}$

These problems will continue to exist except urgent steps are taken to regulate the present practice of the trade in Nigeria. ${ }^{4}$ Successes of TBS, which have been acknowledge by some authors are few with majority of authors agreeing that the practice is dangerous as presently practiced. ${ }^{4,22,23,24,26}$

\section{Knowledge and Practice of Traditional Bone Setters}

Traditional bone setting is regarded as family secret. The training is passed from one generation to another through skills and experience acquired as part of an ancestral heritage. ${ }^{4,19}$ However, there are no scientific inquisitions and there is no peer review of the results obtained. The training is also not formal and not structured. There is no certification and anyone can actually claim to be a practitioner. ${ }^{4,19}$ The treatment of bone injuries is associated with much mythology and superstition. ${ }^{4,19}$ Some TBS use both conventional and herbal medicine. ${ }^{1-}$ ${ }^{4}$ Most of the traditional bone setters manage their clinics with the aid of support staff (nursing assistants) and they operate inpatient services. ., $^{4,10,12}$

The care processes and treatment of fractures at the clinic are same for children, adolescent and adults. ${ }^{4,19}$ The first step in the traditional bone setter algorithm is to identify whether a fracture is open or closed: $:^{3-5}$ The bonesetters refer open fractures to a local clinic or employed support staff for wound care and closure. ${ }^{4}$ Upon the patients return to the bone setters, the limb is manipulated and treated as closed fracture. ${ }^{4}$ For closed fractures, the bone setters identify the fracture site using palpation and clinical signs. ${ }^{1-4}$ Once the fracture site has been identified, the bone setters attempt to reduce the fracture to its anatomical position. ${ }^{4-7}$ Following reduction, the bone setters apply a herbal cream to the affected limb while delivering and incantations. ${ }^{4,15,17,18,19}$

After reduction and embalming, the affected limb is splinted to prevent limb movement. ${ }^{4,15,17,18,19}$ For lower extremity fractures, weight bearing on the affected limb is prohibited. ${ }^{4}$ Splinting material, include cloths, hard cardboard or bamboo and plywood. ${ }^{4}$ Once the limb is splinted, the patient is begun on a standard care pathway, which involves 51 days of complete limb immobilization followed by a 51 - day period of rehabilitation and return to function. ${ }^{4,19}$ During the immobilization period, the splinting materials are changed every four days, at which point the traditional bone setters re-applies the herbal cream and massages the limbs. ${ }^{4,19}$

For patients with lower extremity fractures, during the immobilization period, the patient is given a personal 
mat on which they can be carried around by family members or support staff.

During the second 51 days, patients are gradually mobilized and the bone bonesetters continue to massage and embalm the limb while also counseling the individual on gait training. ${ }^{4}$ The care process in the final 51 days is directed at the discretion of the bone setters based on the signs and symptoms of the patient. ${ }^{4}$ Some of the traditional bone setters make use of $\mathrm{x}$-rays to confirm site of fracture and to confirm reduction during immobilizations. ${ }^{4,20,21,22}$

\section{Methodology}

Enugu state is composed of three senatorial zones, each of which has one major urban town, namely, Enugu, Nsukka and Orji River. The senatorial zones are Enugu North, Enugu East and Enugu west. Enugu State has seventeen local government areas (LGA) with a total population of 3,367,837 people within a total area of $7,618 \mathrm{sq} \mathrm{km} .{ }^{32}$ Enugu is the capital of Enugu State. The population is predominantly Christian religion and the Igbo extraction.

Enugu State people are mainly farmers, traders, and civil servants. Nkanu West LGA is intervention area while Igbo-Etiti is control areas. The distance between the intervention and control areas is approximately 105 kilometers apart. The study will be carried out in two rural LGAs of Enugu State namely Nkanu West and IgboEtiti Local Government Areas.

Nkanu West LGA has headquarters in the town of Agbani, $15 \mathrm{~km}$ from Enugu urban. Nkanu West LGA has a population of 146,697 with total area of $225 \mathrm{sq} \mathrm{km}$ at 2006 census. ${ }^{32}$

Igbo-etiti LGA has headquarters at Ogbede. The local government is about $30 \mathrm{~km}$ from Nsukka urban. It has a population of 208,333 within total areas of $195 \mathrm{sq} \mathrm{km}$ at 2006 census. ${ }^{32}$

\section{Study Design}

It was an interventional study with control (quasi-experimental study) conducted among traditional bone setters. Appendix 1 was interviewer administered questionnaire for traditional bone setters to assess their KAP before and after intervention.

\section{Study Population}

All the traditional bone setters in the study areas were examined.

\section{The inclusion criteria for Traditional Bone Setter are}

1) Must be resident in the community at least 1 year

2) Must be known by the community as traditional bone setters

3) Must not combine orthodox practice and traditional bone setting.

4) Must not have received any training in orthopedic practices.

\section{While the Exclusion criteria includes}

1 Person not recognized by the community as traditional bone setters.

2 Not resident in the community.

3 Have not practiced the traditional bone setting for more than 1 year.

4 Using orthodox methods and traditional methods.

\section{Sample Techniques \\ Selection of study areas}

Enugu State has 3 senatorial zones: Enugu East, Enugu West and Enugu North. From these zones, Enugu East and Enugu North were chosen by simple random sampling by decision of throwing coin. Enugu East was designated the intervention areas and Enugu North the control area. In each of the chosen senatorial zones, one LGA was selected by simple random sampling from a frame of all the LGA in the zone by decision of selecting from a well reshuffled bag containing the names of all Local Government Areas.

\section{Selection of Traditional Bone Setters.}

In each selected LGA, all the traditional bone setters were selected purposively because the numbers of traditional bone setters were not many.

\section{Sample Size Determination}

All the traditional bone setters in the study areas were selected, there was no need for sample size estimation. 


\section{Data Collection}

Training of Interviewers

A total of four interviewers were trained by the researcher for 3 days. They were trained on the general concept of modern orthopedic practices, and specifically on their job requirement of conducting the interview in the field. A copy of research instruments was made available to each and every one of them, during which all the aspects of each of the tools were explained to them. Opportunity was given to them to ask questions and the grey areas cleared.

\section{Research Team}

A total of five people were in the research team. Research team was made up of principal research person who was also the coordinator and investigator. An orthopedic technician was used to demonstrate the use of plaster of Paris and average duration needed for the union of bones. Also two orthopedic nurses were used to demonstrate the care of fractured bones and prevention of sepsis. A social worker to motivate and to affect a behavioral change was included.

\section{Advocacy/ Community entry}

A letter of introduction was obtained from the Department of Community Medicine, University of Nigeria Teaching Hospital to the chairman of the focal Local Government Areas, supervisory council for health and Community leader in the study areas. In addition, the letter was presented to the leader/chairman of Traditional Bone Setters in the Local government areas. Permission and co-operation were obtained for the study. The purpose and benefits of the study were highlighted in the letter of introduction.

\section{Baseline Data Collection for Traditional bone setters Pretesting of questionnaires/Base line data collection for Traditional Bone Setters}

The questionnaire was pre-tested in another Local Government Area that was comparable to the ones in study areas, it was tested for validity. The baseline data on the knowledge, attitudes and practice of traditional bone setters were collected with the aid of pre-tested and structured questionnaire (Appendix 1). Following introduction and explanation, the consent was obtained by the researcher/interviewers.

The baseline data were collected in both intervention area and control areas. The principal researcher went through the data collected by interviewers for possible corrections, omissions and additions before final recording of the data.

\section{Post intervention Data Collection from Traditional Bone Setters}

Immediately after the intervention period and six months following the intervention period, the TBSs were reinterviewed using the same questionnaire to determine the effect of training of the traditional bone setters on the knowledge, attitude and practice concerning the bone setting and also on referrals. Before the post intervention data collection there was continual monitoring, visiting and re-training of TBS on bi-monthly basis, their adherence/compliance to the instructional guidelines on bone management and their challenges were noted.

\section{Training of Traditional Bone Setters}

Only traditional bone setters in the intervention group were trained.

1. On the importance of proper fracture management.

2. The rational for proper fracture management.

3. Proper wound care.

4. Nursing patient under Protective Bed Nets (to protect from mosquito bite and house flies from contaminating wounds).

5. Use of analgesic to reduce pain for better bone reduction.

6. To learn the average duration for bone union

7. To avoid application of local mixture on open wound.

8. To avoid tight splinting and frequent massaging of the affected areas.

9. To avoid frequent losing of splints before the expected duration period for bone union.

10. Storage of drugs like analgesics

11. Referral of complicated cases like open fracture, compound fracture and fractures of special area like skull, thorax, pelvis etc

12. Use of plaster of Paris for immobilization of fractured bones

13. Use of X-ray to confirm bone fracture and also good bone reduction particularly those TBS close to a place where $\mathrm{x}$-ray facilities is available.

14. To use paramedical staff or nurses for minor open wound dressing or administration of analgesics and antibiotics as well as anti-tetanus injection. 
For the Control Groups

At the end of the research, the traditional bone setters were taught the basic orthopedic surgery/care.

\section{Methods of Teaching of Traditional Bone Setters}

1. Verbal, person-to-person interactive communication with the trainers.

2. Use of flipcharts and flannels on the training days.

3. Demonstration of how to use plaster of Paris

4. Demonstration on how to confirm bone fractures and proper reduction using x-ray.

\section{Contents of the training included}

1)Provision of general information on bone complications

2)Importance of better management and better patronage.

3) Recognition of complicated fractures and prompt referrals to formal hospital.

4)Information on general sanitation

5) Simple book recording/keeping

The training of TBSs was done at TBS clinic that was centrally located. At the end of the training TBSs were encouraged to source the material for basic orthopedic care including antibiotics, analgesic and dressing material from nearby health centre.

\section{Variables}

The study examined the following categories of dependent and independent variables.

Dependent (outcome) variables.

1. Knowledge, attitude and practice of Traditional bone setters on fracture management

2. Utilization of x-rays, plaster of Paris, anti-tetanus injections, simple suturing of wound, proper cleansing of wound and insecticide treated nets to prevent houseflies/mosquitoes.

Independent (Input Variables)

1. Socio- Demographic characteristics of respondent (traditional bone setters).

2. Training of the traditional bone setters on simple orthopedic practice, use of $\mathrm{x}$-rays, plasters of Paris and use of insecticide treated nets.

\section{Data Management}

At the end of each field working day, the principal investigator of this study reviewed all questionnaires, and any inconsistence or missing data were verified and or were completed in the field through re-interviews. All data was coded, entered and verified with double entry using SPSS.

\section{Data Analysis}

Bivariate analysis was used with the aid of SPSS Version 16 and Epi-info version 6; respondents were described by their socio-demographic characteristics, a comparison of intervention and control group were checked with the chi-square analysis at base line to determine the differences in their knowledge and practice of Traditional bone setters on traditional bone setting. Chi test analysis was done on KAP with utilization of X-ray services, plaster of Paris (POP), modern orthopedic practices, use of anti-tetanus injection, insecticide treated nets antibiotic and analgesics. It was also carried out at post-intervention period ( 6 months after intervention) to determine the effect of training of traditional bone setters on the uptake of X-ray services, modern orthopedic practices, POP, anti-tetanus injections, antibiotics and insecticide treated nets. Yate`s correction was done during the calculation of chi-square value in the cell less than 5 units. A 5 point likert scale was used to assess the attitudinal changes. For positive attitude, numbers were assigned from descending order, example strongly agreed, agreed, Indifferent, disagreed and strongly disagreed as 5,4,3,2,1 and for negative attitude the numbers were assigned in the ascending order, example 1,2,3,4,5. From above, the mean score, standard deviation (SD), number of persons, the t-test was calculated and p-value determined. For negative attitude, the mean score less than 3 was considered to be good and mean score greater or equal to 3 was taken as poor. In positive attitude, the mean score greater than 3 was taken as good while the mean score of less than or equal to 3 was taken as poor. All the tests of significance were based on a p-level of 0.05 .

\section{Limitations of the Study}

1. The TBS were not willing to leave their clinics and were secretive in their responses to some questions. This affected the accuracy of the reports.

However, this was solved by obtaining the consent and support of the chairman of their union and the community leaders, and the training and re-training exercise after one-day instructional course were done at the TBS clinics. 
2. Poor topography due to raining season and poor transport system affected the study. The study was done when the effect of rain was less and area more accessible and also motorcycles were used.

\section{Ethical Consideration}

Ethical clearance was sought and obtained from the Research and Ethics Committee of the Enugu State University of Technology Teaching Hospital, Enugu, Enugu State, before the study. The traditional bone setters and patients/caregivers were properly informed of the aims and the objectives of the study, after which they were asked to sign the consent form before the interview. Absolute confidentiality of the identity of the participants was maintained throughout the study. There was education and training of the participants (TBS) in the control facilities after the study.

\section{Data Presentation and Analyses}

\section{Table 1: Socio-demographic Characteristics of Bone Setters}

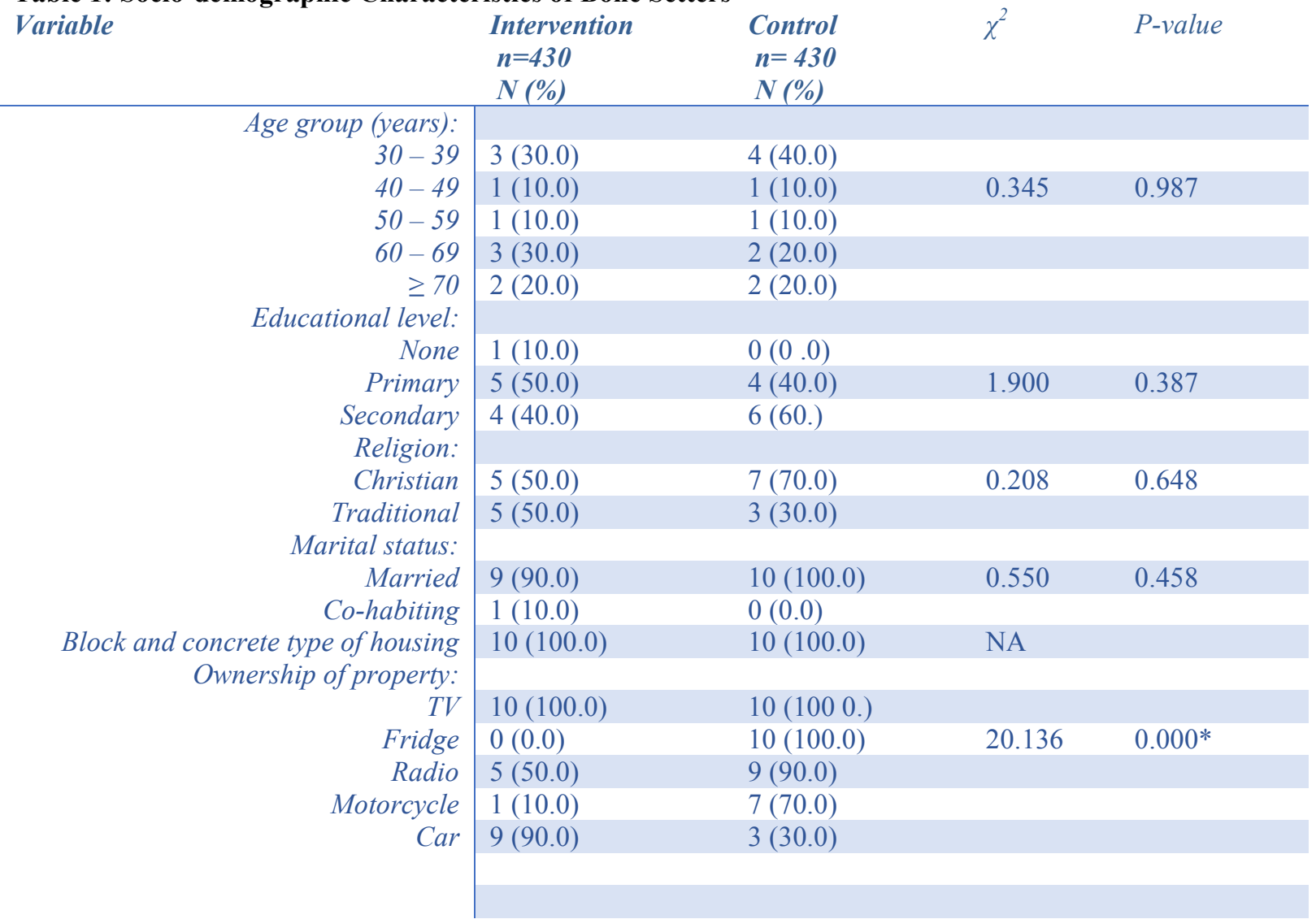

*Statistically significant; NA = Not applicable

Table 1 above shows that there were no significant differences between the study group and the control group in their socio-demographic characteristics. The age group that engaged most into the trade was 30-39 years. All the TBSs had either primary or secondary education. More of the TBSs $(60.0 \%)$ were Christians while the rest were traditionalists. Most of the respondents were married. In the ownership of property, the TBSs in the control group did better than those in the study group. However, there was no statistically significant difference between the two groups. 
Table 2: Knowledge of bone setting by the study group before and after intervention

\begin{tabular}{|c|c|c|c|c|c|c|c|c|}
\hline & \multicolumn{4}{|c|}{ Intervention } & \multicolumn{4}{|l|}{ Control } \\
\hline Variable & $\begin{array}{l}\text { Pre } \\
(n=430) \\
N(\%)\end{array}$ & $\begin{array}{l}\text { Post } \\
(n=430) \\
N(\%)\end{array}$ & $\chi^{2}$ & $\begin{array}{l}\mathbf{p} \\
\text { value }\end{array}$ & $\begin{array}{l}\text { Pre } \\
(n=430) \\
N(\%)\end{array}$ & $\begin{array}{l}\text { Post } \\
(n=430 \\
) \\
N(\%)\end{array}$ & $\chi^{2}$ & $\begin{array}{l}\mathbf{p} \\
\text { value }\end{array}$ \\
\hline $\begin{array}{l}\text { Having provisions for in- } \\
\text { patients help in their } \\
\text { management }\end{array}$ & $10(100.0)$ & $\begin{array}{c}10 \\
(100.0)\end{array}$ & NA & & $10(100.0)$ & $\begin{array}{c}10 \\
(10.0)\end{array}$ & NA & \\
\hline $\begin{array}{l}\text { Nurses and paramedical } \\
\text { can assist in patient } \\
\text { management }\end{array}$ & $0(0.0)$ & $\begin{array}{c}10 \\
(100.0)\end{array}$ & 19.785 & $0.000^{*}$ & $1(10.0)$ & $1(10.0)$ & 0.000 & 1.000 \\
\hline $\begin{array}{l}\text { Sterilizers can help in } \\
\text { making } \\
\text { instruments germ free }\end{array}$ & $1(10.0)$ & $\begin{array}{c}10 \\
(100.0)\end{array}$ & 12.929 & $0.000^{*}$ & $0(0.0)$ & $0(0.0)$ & NA & \\
\hline $\begin{array}{l}\text { Providing patients with } \\
\text { ITNs prevents wound } \\
\text { infection by flies and } \\
\text { mosquito bites }\end{array}$ & $10(100.0)$ & $\begin{array}{c}10 \\
(100.0)\end{array}$ & NA & & $\begin{array}{c}10 \\
(100.0)\end{array}$ & $\begin{array}{c}10 \\
(100.0)\end{array}$ & NA & \\
\hline $\begin{array}{l}\text { Knowledge of bone setting } \\
\text { was transferred from } \\
\text { parents or older TBSs }\end{array}$ & $4(40.0)$ & $4(40.0)$ & NA & & $\begin{array}{c}10 \\
(100.0)\end{array}$ & $\begin{array}{c}10 \\
(100.0)\end{array}$ & NA & \\
\hline $\begin{array}{l}\text { Knowledge of bone setting } \\
\text { was transferred from } \\
\text { orthopaedic surgeons }\end{array}$ & $4(40.0)$ & $4(40.0)$ & NA & & $10(100.0)$ & $0(0.0)$ & 19.785 & $0.000 *$ \\
\hline $\begin{array}{l}\text { Types of bone fracture } \\
\text { known: }\end{array}$ & & & & & & & & \\
\hline Simple closed & $\begin{array}{c}10 \\
(100.0)\end{array}$ & $\begin{array}{c}10 \\
(100.0)\end{array}$ & & & $\begin{array}{c}10 \\
(100.0)\end{array}$ & $\begin{array}{c}10 \\
(100.0)\end{array}$ & & \\
\hline Simple open & $\begin{array}{c}10 \\
(100.0)\end{array}$ & $\begin{array}{c}10 \\
(100.0)\end{array}$ & 0.541 & 0.969 & $\begin{array}{c}10 \\
(100.0)\end{array}$ & $\begin{array}{c}10 \\
(100.0)\end{array}$ & & \\
\hline Compound open & $\begin{array}{c}10 \\
(100.0)\end{array}$ & $\begin{array}{c}10 \\
(100.0)\end{array}$ & & & $\begin{array}{c}10 \\
(100.0)\end{array}$ & $\begin{array}{c}10 \\
(100.0)\end{array}$ & 0.437 & 0.979 \\
\hline Compound closed & $9(90.0)$ & $\begin{array}{c}10 \\
(100.0)\end{array}$ & & & $\begin{array}{c}10 \\
(100.0)\end{array}$ & $\begin{array}{c}10 \\
(100.0)\end{array}$ & & \\
\hline Incomplete & $\begin{array}{c}10 \\
(100.0)\end{array}$ & $7(70.0)$ & & & $7(70.0)$ & $\begin{array}{c}10 \\
(100.0)\end{array}$ & & \\
\hline $\begin{array}{l}\text { Knowledge and ability to } \\
\text { diagnose fracture and } \\
\text { carry out bone reduction }\end{array}$ & $0(0.0)$ & $\begin{array}{c}10 \\
(100.0)\end{array}$ & 19.785 & $0.000^{*}$ & $0(0.0)$ & $\begin{array}{c}10 \\
(100.0)\end{array}$ & 19.785 & $0.000^{*}$ \\
\hline $\begin{array}{l}\text { *Statistically significant; NA } \\
\text { The general knowledge } \\
\text { provide the in-patients with } \\
\text { knew the importance of havir } \\
\text { they realized the need to hav } \\
\text { of them at the end of the train } \\
\text { The knowledge of TBS } \\
\text { with respect to provisions fo } \\
\text { sterilizers or use of ITNs. Al } \\
\text { there was significant drop at } \\
\text { 0.000). Surprisingly, at the e } \\
\text { proper bone reduction. }\end{array}$ & $\begin{array}{l}\text { Not applic } \\
\text { of bone set } \\
\text { TNs which } \\
\text { g nurses an } \\
\text { sterilizers } \\
\text { ing acknowl } \\
\text { in the contr } \\
r \text { in-patient } \\
\text { o knowledg } \\
\text { he end of th } \\
\text { ad of the st }\end{array}$ & $\begin{array}{l}\text { able; ITN } \\
\text { ng by the } \\
\text { ecorded } n \\
\text { other par } \\
\text { order to } \\
\text { dged that } \\
1 \text { group, a } \\
\text { having } n \\
\text { of type o } \\
\text { e study ab } \\
\text { dy there }\end{array}$ & $\begin{array}{l}\text { Insectic } \\
\text { esponde } \\
\text { change. } \\
\text { nedical } \\
\text { ake thei } \\
\text { thopedi } \\
\text { the end } \\
\text { ed for s } \\
\text { fracture } \\
\text { it acquis } \\
\text { s signifi }\end{array}$ & $\begin{array}{l}\text { ide Trea } \\
\text { ts impro } \\
\text { After th } \\
\text { taff in th } \\
\text { surgical } \\
\text { surgeor } \\
\text { of the st } \\
\text { rvices o } \\
\text { did not } \\
\text { ition of } 1 \\
\text { cant incr }\end{array}$ & $\begin{array}{l}\text { d Bednet } \\
\text { ved after tr } \\
\text { training, a } \\
\text { eir clinics } \\
\text { instruments } \\
\text { could tran } \\
\text { dy did not } \\
\text { nurses/par } \\
\text { hange at th } \\
\text { lowledge fr } \\
\text { ase and ab }\end{array}$ & $\begin{array}{l}\text { ning, exc } \\
\text { the tradit } \\
=0.000 \text { ). } \\
\text { yerm free. } \\
\text { er knowle } \\
\text { low any } \\
\text { medical } \\
\text { end of th } \\
\text { m orthop } \\
\text { ty to con }\end{array}$ & $\begin{array}{l}\text { pt in the } \\
\text { ional bon } \\
\text { Post-inter } \\
\text { Regrettal } \\
\text { dge to the } \\
\text { ignificant } \\
\text { taff, the } \\
\text { study. H } \\
\text { dic surge } \\
\text { irm fract }\end{array}$ & $\begin{array}{l}\text { need to } \\
\text { setters } \\
\text { vention, } \\
\text { ly none } \\
\mathrm{m} \text {. } \\
\text { change } \\
\text { eed for } \\
\text { owever, } \\
\text { ons ( } \mathrm{p}= \\
\text { ares and }\end{array}$ \\
\hline
\end{tabular}


Table 3: Knowledge of Management of Fractures

\begin{tabular}{|c|c|c|c|c|c|c|c|c|}
\hline \multirow[b]{2}{*}{ Variable } & \multicolumn{4}{|c|}{ Intervention } & \multicolumn{3}{|l|}{ Control } & \multirow[b]{2}{*}{ Pvalue } \\
\hline & $\begin{array}{l}\text { Before } \\
\text { Freq. } \\
(\%)\end{array}$ & $\begin{array}{l}\text { After } \\
\text { Freq. } \\
(\%)\end{array}$ & $\chi^{2}$ & Pvalue & $\begin{array}{l}\text { Before } \\
\text { Freq. } \\
(\%)\end{array}$ & $\begin{array}{l}\text { After } \\
\text { Freq. } \\
(\%)\end{array}$ & $\chi^{2}$ & \\
\hline \multicolumn{9}{|l|}{$\begin{array}{l}\text { Symptoms and signs of wound } \\
\text { infection }\end{array}$} \\
\hline Bad odour & $9(90.0)$ & $\begin{array}{c}10 \\
(100.0)\end{array}$ & & & 10 & $\begin{array}{c}10 \\
(100.0)\end{array}$ & & \\
\hline Colour change & $9(90.0)$ & $9(90.0)$ & 1.490 & 0.828 & 9 & $\begin{array}{c}10 \\
(100.0)\end{array}$ & 0.718 & 0.949 \\
\hline Abscess formation & $9(90.0)$ & $\begin{array}{c}10 \\
(100.0)\end{array}$ & & & 10 & $\begin{array}{c}10 \\
(100.0)\end{array}$ & & \\
\hline Pains & $4(40.0)$ & $2(20.0)$ & & & 2 & 2 & & \\
\hline Swollen tissue & $7(70.0)$ & $4(40.0)$ & & & 4 & 2 & & \\
\hline \multicolumn{9}{|l|}{$\begin{array}{l}\text { Symptoms and signs of } \\
\text { tetanus }\end{array}$} \\
\hline Convulsions & $\begin{array}{c}10 \\
(100.0)\end{array}$ & $\begin{array}{c}10 \\
(100.0)\end{array}$ & & & $\begin{array}{c}10 \\
(100.0)\end{array}$ & $\begin{array}{c}10 \\
(100.0)\end{array}$ & & \\
\hline Fever & $\begin{array}{c}10 \\
(100.0)\end{array}$ & $\begin{array}{c}10 \\
(100.0)\end{array}$ & 0.000 & 1.000 & $\begin{array}{c}10 \\
(100.0)\end{array}$ & $\begin{array}{c}10 \\
(100.0)\end{array}$ & 0.000 & 1.000 \\
\hline Refusal to eat & $\begin{array}{c}10 \\
(100.0)\end{array}$ & $\begin{array}{c}10 \\
(100.0)\end{array}$ & & & $\begin{array}{c}10 \\
(100.0)\end{array}$ & $\begin{array}{c}10 \\
(100.0)\end{array}$ & & \\
\hline Shortage of blood & $\begin{array}{c}10 \\
(100.0)\end{array}$ & $\begin{array}{c}10 \\
(100.0)\end{array}$ & & & $\begin{array}{c}10 \\
(100.0)\end{array}$ & $\begin{array}{c}10 \\
(100.0)\end{array}$ & & \\
\hline $\begin{array}{l}\text { Sterilization of instrument and } \\
\text { hygienic dressing of wound } \\
\text { help to prevent infection and } \\
\text { tetanus }\end{array}$ & $0(0.0)$ & $\begin{array}{c}10 \\
(100.0)\end{array}$ & 19.785 & $0.000 *$ & $0(0)$. & $0(0.0)$ & NA & \\
\hline \multicolumn{9}{|l|}{$\begin{array}{l}\text { Materials used to immobilize } \\
\text { fracture: }\end{array}$} \\
\hline Bamboo stick & $2(20.0)$ & $0(0.0)$ & & & $3(30.0)$ & $3(30.0)$ & & \\
\hline Any suitable stick with cloth & $8(80.0)$ & $4(40.0)$ & NA & & $7(70.0)$ & $7(70.0)$ & 0.000 & 1.000 \\
\hline Plaster of Paris & $0(0.0)$ & $6(60.0)$ & & & $1(10.0)$ & $1(10.0)$ & & \\
\hline Pieces of iron & $0(0.0)$ & $0(0.0)$ & & & $1(10.0)$ & $1(10.0)$ & & \\
\hline $\begin{array}{l}\text { Plaster of Paris is better to } \\
\text { mobilize a fracture }\end{array}$ & $3(30.0)$ & $\begin{array}{c}10 \\
(100.0)\end{array}$ & 7.912 & $0.005^{*}$ & $0(0.0)$ & $0(0.0)$ & NA & \\
\hline $\begin{array}{l}\text { Continual adjustment of } \\
\text { splinting can lead to mal- } \\
\text { union or non-union of bone }\end{array}$ & $1(10.0)$ & $\begin{array}{c}10 \\
(100.0)\end{array}$ & 12.929 & $0.000^{*}$ & $0(0.0)$ & $0(0.0)$ & NA & \\
\hline $\begin{array}{l}\text { Knowledge of management of } \\
\text { complicated bone fracture }\end{array}$ & $8(80.0)$ & $4(40.0)$ & 1.875 & 0.171 & $4(40.0)$ & $1(10.0)$ & 1.067 & 0.302 \\
\hline
\end{tabular}

*Statistically significant; NA = Not applicable

The signs and symptoms of wound and tetanus infection did not change after training. However, the need for sterilization of instruments and hygienic dressing improved significantly after training $(p=0.000)$. Equally, the knowledge of the need for POP improved significantly $(\mathrm{p}=0.005)$. Interestingly, the acknowledgement that continual adjustment of splitting could lead to mal-union or non-union improved statistically after training $(p=$ 0.000 ). However, though not significantly, the accepted knowledge on management of complicated bone injury before the training dropped from $80.0 \%$ to $40.0 \%$ at the end of the training.

The knowledge of management of fracture by the control group at the end of the study, did not show any significant change. 
Table 4: Attitudes of the study group towards bone setting before and after intervention

\begin{tabular}{|c|c|c|c|c|c|c|c|c|}
\hline \multirow[b]{2}{*}{ Variable } & \multicolumn{4}{|c|}{ Intervention } & \multicolumn{3}{|c|}{ Control } & \multirow[b]{2}{*}{ Pvalue } \\
\hline & $\begin{array}{l}\text { Before } \\
\text { Freq. } \\
(\%)\end{array}$ & $\begin{array}{l}\text { After } \\
\text { Freq. } \\
(\%)\end{array}$ & $\chi^{2}$ & Pvalue & $\begin{array}{l}\text { Before } \\
\text { Freq. } \\
(\%)\end{array}$ & $\begin{array}{l}\text { After } \\
\text { Freq. } \\
(\%)\end{array}$ & $\chi^{2}$ & \\
\hline \multicolumn{9}{|l|}{ Negative attitudes: } \\
\hline $\begin{array}{lcr}\text { Orthopaedic } \quad \begin{array}{c}\text { surgeons } \\
\text { unnecessary amputations }\end{array} & \begin{array}{r}\text { and } \\
\text { ampusen } \\
\text { blood transfusions }\end{array}\end{array}$ & $\begin{array}{c}4.0 \pm \\
0.1\end{array}$ & $\begin{array}{c}2.1 \pm \\
0.3\end{array}$ & 19.00 & $0.000 *$ & $\begin{array}{c}4.5 \pm \\
0.5\end{array}$ & $\begin{array}{c}4.5 \pm \\
0.5\end{array}$ & 0.000 & 1.000 \\
\hline $\begin{array}{l}\text { Orthopaedic surgeons demand } \\
\text { high fees from patients before } \\
\text { treatment }\end{array}$ & $\begin{array}{c}4.5 \pm \\
0.5\end{array}$ & $\begin{array}{c}2.9 \pm \\
0.9\end{array}$ & 4.91 & $0.000 *$ & $\begin{array}{c}4.5 \pm \\
0.5\end{array}$ & $\begin{array}{c}4.5 \pm \\
0.5\end{array}$ & 0.000 & 1.000 \\
\hline \multicolumn{9}{|l|}{ Positive attitudes: } \\
\hline $\begin{array}{l}\text { Sharing experiences with other } \\
\text { stakeholders in bone management } \\
\text { helps in better bone management }\end{array}$ & $\begin{array}{c}1.9 \pm \\
0.3\end{array}$ & $\begin{array}{c}4.5 \pm \\
0.5\end{array}$ & 14.10 & $0.000 *$ & $\begin{array}{c}2.5 \pm \\
0.5\end{array}$ & $\begin{array}{c}2.5 \pm \\
0.5\end{array}$ & 0.000 & 1.000 \\
\hline $\begin{array}{l}\text { I accept to have further training } \\
\text { since it will help me to have more } \\
\text { patients }\end{array}$ & $\begin{array}{c}4.7 \pm \\
0.5\end{array}$ & $\begin{array}{c}4.8 \pm \\
0.4\end{array}$ & 0.49 & 0.627 & $\begin{array}{c}4.3 \pm \\
0.5\end{array}$ & $\begin{array}{c}4.3 \pm \\
0.5\end{array}$ & 0.000 & 1.000 \\
\hline
\end{tabular}

*Statistically significant

Negative attitude: mean score of $<3=$ good, while mean score of $\geq=$ poor

Positive attitude: mean score of $\geq 3=$ good, while mean score of $<3=$ poor

Table 4 shows that the negative attitudes of the traditional bone setters improved significantly after the training. The mean scores were less than three i.e. good. They now realized that orthopedic surgeons do not give unnecessary amputations and blood transfusion nor charge high fees before treatment. There was equally an improvement in the positive attitudes. The traditional bone setters were now willing to share their experiences with other stakeholders in bone management $(p=0.000)$. However, there was no statistically significant improvement in their willingness to undergo further training.

The attitudes of the TBSs in the control group remained poor at the end of the study. The mean score for negative attitude was more than 3 while for positive attitude the mean score was less than 3 . However, the mean score of 4.3 was a good one, accepting to have training in order to improve the number of patients in the clinics.

Table 5: Practice of bone setting by the study group before and after intervention

\begin{tabular}{|c|c|c|c|c|c|c|c|c|}
\hline & \multicolumn{4}{|c|}{ Intervention } & \multicolumn{3}{|c|}{ Control } & \multirow[b]{2}{*}{ Pvalue } \\
\hline Variable & $\begin{array}{l}\text { Before } \\
\text { Freq. } \\
(\%)\end{array}$ & $\begin{array}{l}\text { After } \\
\text { Freq. } \\
(\%)\end{array}$ & $\chi^{2}$ & Pvalue & $\begin{array}{l}\text { Before } \\
\text { Freq. } \\
(\%)\end{array}$ & $\begin{array}{l}\text { After } \\
\text { Freq. } \\
(\%)\end{array}$ & $\chi^{2}$ & \\
\hline $\begin{array}{l}\text { Training of other people in } \\
\text { traditional bone setting }\end{array}$ & $2(20.0)$ & $\begin{array}{c}10 \\
(10.0)\end{array}$ & 10.208 & $0.001 *$ & $0(0.0)$ & $0(0.0)$ & NA & \\
\hline $\begin{array}{l}\text { Use of antibiotics and/or anti- } \\
\text { tetanus toxoid to prevent } \\
\text { wound infection and/or tetanus }\end{array}$ & $0(0.0)$ & $\begin{array}{c}10 \\
(10.0)\end{array}$ & 19.785 & $0.000^{*}$ & $0(0.0)$ & $0(0.0)$ & NA & \\
\hline $\begin{array}{l}\text { Referral of patients with } \\
\text { serious fracture to orthopaedic } \\
\text { surgeon } \\
\text { management }\end{array}$ & $5(50.0)$ & $\begin{array}{c}10 \\
(10.0)\end{array}$ & 4.267 & $0.039^{*}$ & 8 & $0(0.0)$ & 10.208 & $0.001^{*}$ \\
\hline
\end{tabular}

*Statistically significant

The practice of bone setting by TBSs in the study group after training statistically improved. The acceptance of training of other people in the clinics and use of antibiotics/anti-tetanus toxoid were statistically significant after training of the TBS in the study group. Interestingly, the referral of patients with serious fracture to orthopedic surgeons for better management improved significantly after training $(\mathrm{p}=0.039)$.

There was no improvement in the practice of bone setting by the control group, as shown by the training of other people in traditional bone setting as well as the use of antibiotics and/or anti-tetanus toxoid to prevent wound infection and tetanus. Regrettably, there was no referral of patients with serious fracture to orthopedic surgeons for better management.

\section{Discussion of Finding}

Most of the traditional bone setters were male. This was expected since most of them underwent a long 
apprenticeship which was not perceived to be easy for women. In addition to that, culturally people prefer to transfer their knowledge and practices to their male issues because they like to retain the practices in the family. Bone management is considered to be tedious and therefore an exclusive reserve of men. There were no significant differences between the study and the control groups with regard to the socio-demographic characteristics. The age group that engaged most into traditional bone setting was $30-39$ years. The age of $30-$ 39 years is age when most people have capacity to work. Most of the TBSs were married; this was quite expected because culturally more respect is given to married people and this fact will enhance the patronage of their services by the bone injury patients.

Most of the TBSs studied had either primary or secondary education. This fact is very important because it would facilitate better understanding of instructional courses and seminars. The finding is comparable to a study in Maiduguri, Borno State of Nigeria. ${ }^{6}$ An estimated $60.0 \%$ of TBSs were Christians and the rest Traditionalists. It is not surprising to have such figures, because the areas covered are predominately occupied by the two religious.

All the TBSs, studied had modern block houses. This is expected because of high patronage of TBSs which cuts across the society. This patronage empowers them adequately to own block houses.

In addition, most of the TBSs owned television sets, fridges, motorcycles and cars. This is reflective of high patronage they enjoy as well as the huge financial reward. However, the TBSs that made up the control group have more personal properties. This finding is in line with a study in Maiduguri, Borno State on high patronage of TBSs and their huge financial returns ${ }^{6}$.

Most of the TBSs that were studied had in-patient facilities which help them for better management of patients. This finding is comparable to studies that were carried out both in northern part of Nigeria and in India respectively where they studied the in-patient facilities and exposure to mosquito bites ${ }^{30,31}$. Some of the TBSs studied preferred to make use of nurses or paramedical staff to treat the wounds and administer injections while others were indifferent about the benefit of using them. This finding is similar to a study that was conducted in Delta State, Nigeria where a good number of TBSs were using trained orthodox paramedical staff ${ }^{8}$. There is now an increasing awareness among the TBSs in the developing countries of the need to imbibe modern medical practices. They have witnessed the benefits evidenced by a reduction in morbidity and mortality from such practices. This may have resulted from their having attended numerous workshops and instructional courses that encourage such practices.

Having provisions for in-patients help in their management, most of the TBSs visited prior to training, had in-patient facilities and such facilities have been in existence since commencement of their clinics. This finding is conformity to studies done in south western Nigeria and Ghana which was perceived to be an important practice. ${ }^{9,18}$

On acquisition of knowledge from parents or older traditional bone setters, most of them agreed on acquiring such skills from aforesaid persons because culturally parents like to retain such practices in their family by transferring the skill to their male issues. In addition to that TBSs like to be secretive to avoid unwanted people acquiring the skills. This finding is similar to studies were they found that TBSs activities were shrouded in mystery and secrecy. ${ }^{4,19}$ The TBSs that made up the control group at the end of the study refused to acknowledge that they acquired their practicing skills from orthodox surgeons. This denial of acquiring skills from orthopedic surgeons may be due to rivalry that exists between the TBSs and orthopedic surgeons. On the knowledge of types of fracture both groups of TBSs maintained that they knew all types of fractures prior to training and at the end of study. Not much improvement was noted in their knowledge of types of bone fracture at the end of the study. However, their knowledge and ability to diagnose fracture and proper bone reduction improved significantly after training of the study group with a $p$-value of 0.000 . This finding is in conformity with a study that was done in private hospitals in South-South region of Nigeria ${ }^{25}$. Prior to training, the TBSs knew signs and symptoms of wound and tetanus infection. After training, there was no significant change in the knowledge this because they have conversant with the signs and symptoms of tetanus infection in their practice.

Nevertheless, the importance of sterilization of instruments and hygienic dressing of wounds to prevent infection and tetanus improved significantly with a p-value of o.ooo. In addition, post intervention, the TBSs in study group recognized the need for the use of plaster of Paris and this improved significantly with a p-value of 0.005. Another important development was acknowledgement by the TBSs in the study group that the continual adjustment of splinting could lead to mal-union or non-union of bone. This fact was asserted by the $p$-value of 0.000. The acceptance of this made TBSs to look for better alternative which is plaster of Paris. The initial acceptance of knowledge of management of complicated bone fracture dropped from $80.0 \%$ to $40.0 \%$ after training.

The negative attitudes of TBSs that orthopedic surgeons cause unnecessary amputation and blood transfusion together with surgeons demanding high fees from patients before treatment significantly changed after the intervention. The positive attitudes on sharing experiences with other stakeholders in bone management equally changed significantly to be good by their accepting to share experiences with others. At the end of the 
training, the TBSs became more willing to be trained. They recognized the important of acquiring skills in modern orthopedic practices.

The knowledge of bone setting by the TBSs in the study group improved significantly after training. The training of other people, use of antibiotics/Toxoid injections and referral of serious bone injury patient to orthopedic surgeons significantly improved. This finding is similar to a study in Calabar Southern part of Nigeria where TBSs imbibed the modern orthopedic practices after training ${ }^{28}$.

On the other hand, the knowledge of bone setting by the TBSs in the control group at the end of the study did not record any change except the knowledge that the skills of bone setting were not acquired from orthopedic surgeons. The attitudes of the TBSs of the control group towards bone setting remained poor at the end of the study. The TBSs of the control group did not shift from their attitudes towards orthopedic surgeons or in sharing experiences with other stakeholders.

Surprisingly, the TBSs of the control group accepted to have further training which was a good attitudinal changed, despite the fact that they did not have any training. This can augur very well for their skill improvement. In addition, the practice of TBSs that made up the control group did not changed except referral of serious fracture to orthopedic surgeon which improve remarkably with a p-value of 0.001 . This willingness to refer their patients will hopefully reduce the level of morbidity and mortality accruable to these problems.

\section{Conclusions}

From the study, there were remarkable improvements in the management of bone fracture by TBSs after training. The knowledge, attitudes and practices of TBSs improved significantly after training on basic orthopedic practices. There was also an improvement on prompt referral of serious fractures to orthopedic surgeons for better management.

\section{Recommendations}

At the end of the study, based on the findings, the following recommendations were made:

1. Government should organize regular training of traditional bone setters through instructional workshops and seminars.

2. Important stakeholders in health care delivery at the grass root level such as the Head of primary health centres and supervisory counselors of health should monitor the activities of the TBSs in their various localities. This will hopefully enlighten the government as to the appropriate action to be taken in order to improve the situation on ground.

\section{References}

1. World Health Organization. WHO Traditional medicine surgery 2002 -2005. Genera, World Health Organization 2002.

2. World Health Organization. Consultation meeting on Traditional Medicine and Modern Medicine: Harmonizing the two approaches. Geneva World Health Organization 1999 (document reference TM/ICP/TM/001/RB/98-RS/99/GE/32 (CM)

3. World Health Organization. Promoting the role of traditional medicine in health systems. A strategy for the African Region 2001 - 2010 Harare, World Health Organization 2000 (document reference AFR/RC50/Doc 9

4. Data AA, Yinusa W, Giwa SO. Review of the practice of traditional bone setting in Nigeria. African Health Sciences, 2001; 11(2):350-9

5. Thann. OA. Factors Influencing patronage of Traditional bone setters. WAJM 2000; 1(3):220-224

6. Ngohi BU. Patronage of traditional bone setter and rejection of Orthodox care in Maiduguri: geography department University of Maiduguri journal, 2009 1:12 - 17

7. Ogunlusi DO, Ikem IC, Oginni O. Why patient patronize traditional bone setters. The internet Journal of Orthopedic surgery 2007 Vol. 4 No 2

8. Onuminya JE. The role of the traditional bone setters in primary fracture in Nigeria S. Afric Med J. 2004 94/80.652-81

9. Along TO, Dango AC, Nottidge TE, Omololu AB, Ogunlade SO. Traditional bone setters in south western Nigeria - friends or foes? WAJM, 2004: 23(1) 81-84

10. Omololu AB, Ogunlade SO, Gopaldsani VR The practice of traditional bone setting. Training algorithm. Clin Orthop Relat Rev 2008, 4662392 - 2398

11. Ikpeme IA, Udosen AM, Okereke-kpa I. Patient perceptions of traditional bone setting in Calabar, Southsouth, Nigeria. Port Harcourt Med J. 2007: 1: 104 - 107

12. Udosen AM, Otei OD, Onuba O Role of traditional bone setters in Africa; experience in Calabar, Southsouth, Nigeria. Annals of African Medicine 2006: 514/:170 - 173 
13. Nkele CM. Patterns of occurrence, management and prevention of trauma in Nigerian oil Industry. Nigerian Journal of Orthopedics and Trauma 2000; 2:97 - 100

14. Thanni OA. Akindipe JA, Alausa OK, Pattern and outcome of treatment of musculo skeletal conditions by traditional bone setters in southwest Nigeria. Nigerian Journal of orthopedics and Trauma 2003; 2:112 - 115

15. Udosen AM. Traditional bone setting in African: Counting the cost. The Vol 7 M I Internet Journal of Alternate Medicine 2009.

16. Marwick C. Complementary Medicine must prove it worth. BMJ 2005; 350: 166

17. Addis G, Abebe D, Genebo T, Urga K. Perceptions and practices of modern and traditional medicine in Shirka District, Arsizone Ethiopia. Ethiopian Journal of Health Development 2002:16: 19 - 29

18. Aries MJ, Joosten H, Wegdam H, Vander Geest S. Fracture treatment by bone setters in central Ghana patient explain their choices and experiences Tropical Med Int. Health. 2007: 12(4): $564-574$

19. Agarwal A, Agarwal R. The practice and tradition of bone setting. Education Health (Abingdon) $2010: 23$ (1). 225

20. Solughern B.A. The complication seen from the treatment by traditional bone setters, WAJM, 2003; 22(343 $-345)$

21. Solagbera BA. Long bone fractured treated by TBS. A study of patient's doctor 2005, 35. $106-107$

22. Ololorun DA, Oladiran 10, Aderiran A. Complications of fracture treatment by traditional bone setters in Southwest Nigeria. FAM Pract. 2001, Dec, 18 (6) $635-7$

23. Nwankwo OE, Katchy AU, Limb gangrene following treatment of limb injury by traditional bone setters: report of 15 consective cases. Niger postgrad. Medicine J. 2005 March; 12(1): $57-60$

24. Onuminya JE, Obekpa PO, Ihezue HC, major amputations in Nigeria, a plea to educate traditional bone setters S.Africa Med.J 2006 ;96(4):320-2

25. Ekere AU. The Scope of extremity amputations in private hospital in south south region of Nigeria. Niger $\mathbf{J}$ Med. 2003 Oct-Dec: 12(4) 225-8

26. Eshete M. The prevention of traditional bone setter's gangrene J. Bone Joint Surg. 2005 Jan 87(1): $102-3$

27. Dada A, Giwa SO, Yinusa W, Ugbeye M, Gbadegesin S: Complications of treatment of musculo-skeletal injuries by bone setter.WAJM: 2009; 28(1): 43-47

28. Onuminya J.T. Performance of a trained traditional bone setters in primary fracture care S. Africa Med. J 2006 April; 96(4): 320 - 2

29. Udosen AM. The Role of Orthopedic and Trauma assistants in improving rural orthopedic and trauma care Annals of African Medicine 2004: 3:1502

30. Nwadiaro HC, Oziolo KM, Nwadiaro PO, Kidmas AT, Oboiren M. Determinants of Patronage of Traditional bone setters in the Middle belt of Nigeria. Nig J. Med. 2008; 17: $356-359$

31. Patter K. A traditional bone setting in south India. Afri. Health SU. 2011; 11(2) $262-5$

32. National Bureau of stastitics.2006 population census. National population commission [NPC] Nigeria, edition 2007. 